\title{
Occupational health and safety considerations for women employed in core mining positions
}

\begin{tabular}{|c|c|}
\hline \multicolumn{2}{|l|}{$\begin{array}{l}\text { Authors: } \\
\text { Doret Botha }{ }^{1} \\
\text { Freek Cronjé }^{2}\end{array}$} \\
\hline \multicolumn{2}{|c|}{$\begin{array}{l}\text { Affiliations: } \\
\text { 'School of Social and } \\
\text { Government Studies, } \\
\text { North-West University, } \\
\text { Potchefstroom Campus, } \\
\text { South Africa }\end{array}$} \\
\hline $\begin{array}{l}{ }^{2} \text { Bench Marks } \\
\text { CSR, North-W } \\
\text { Potchefstroom } \\
\text { South Africa }\end{array}$ & $\begin{array}{l}\text { Centre for } \\
\text { est University, } \\
\text { Campus, }\end{array}$ \\
\hline \multicolumn{2}{|c|}{$\begin{array}{l}\text { Correspondence to: } \\
\text { Doret Botha }\end{array}$} \\
\hline \multicolumn{2}{|c|}{$\begin{array}{l}\text { Email: } \\
\text { doret.botha@nwu.ac.za }\end{array}$} \\
\hline \multicolumn{2}{|c|}{$\begin{array}{l}\text { Postal address: } \\
\text { Private Bag X6001, } \\
\text { Potchefstroom 2520, } \\
\text { South Africa }\end{array}$} \\
\hline \multicolumn{2}{|c|}{$\begin{array}{l}\text { Dates: } \\
\text { Received: } 18 \text { June } 2014 \\
\text { Accepted: } 13 \text { Feb. } 2015 \\
\text { Published: } 02 \text { June } 2015\end{array}$} \\
\hline \multicolumn{2}{|c|}{$\begin{array}{l}\text { How to cite this article: } \\
\text { Botha, D., \& Cronjé, F. } \\
\text { (2015). Occupational health } \\
\text { and safety considerations } \\
\text { for women employed in } \\
\text { core mining positions. SA } \\
\text { Journal of Human Resource } \\
\text { Management/SA Tydskrif vir } \\
\text { Menslikehulpbronbestuur, } \\
\text { 13(1), Art. \#652, } 12 \text { pages. } \\
\text { http://dx.doi.org/10.4102/ } \\
\text { sajhrm.v13i1.652 }\end{array}$} \\
\hline \multicolumn{2}{|c|}{$\begin{array}{l}\text { Note: } \\
\text { This research formed part of } \\
\text { Dr Botha's PhD thesis at the } \\
\text { North-West University. }\end{array}$} \\
\hline \multicolumn{2}{|c|}{$\begin{array}{l}\text { Copyright: } \\
\text { (C) 2015. The Authors. } \\
\text { Licensee: AOSIS } \\
\text { OpenJournals. This work is } \\
\text { licensed under the Creative } \\
\text { Commons Attribution } \\
\text { License. }\end{array}$} \\
\hline \multicolumn{2}{|l|}{ Read online: } \\
\hline 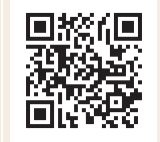 & $\begin{array}{l}\text { Scan this QR } \\
\text { code with your } \\
\text { smart phone or } \\
\text { mobile device } \\
\text { to read online. }\end{array}$ \\
\hline
\end{tabular}

Orientation: Despite various liberalisation and feminisation processes with regard to gender and sex roles, traditionalistic typologies, especially in terms of occupational roles, are seemingly very reluctant to disappear from relevant theoretical discourses, as well as in practice. One of the main issues remains the terrain of physical work. Although women all over the world have been involved in mining activities for centuries, the mining industry has not been an obvious career choice for women. In South Africa, new mining legislation aims to rectify previous inequalities and disadvantages in the mining sector and specifically provides for the inclusion of women in core mining activities. Although well intended, women's involvement in the core business of mining also exposes them to the various hazards related to mine work.

Research purpose: This research determined perceptions regarding the health and safety of women working in core mining positions.

Motivation for the study: Currently there is a paucity of published data regarding health and safety challenges pertaining to women employed in the core business of mining.

Method: Quantitative and qualitative research paradigms were used (mixed method research design). Quantitative data were collected by means of a structured questionnaire. Qualitative data were collected by means of individual interviews and group interviews.

Main findings: From the literature review and the empirical findings it is evident that various factors (physical work capacity, anthropometry and body composition, personal protective equipment, treatment during pregnancy and security measures) need to be considered to ensure the health and safety of women employed in core mining positions.

Practical/managerial implications: It is evident from the research that exceptional attention should be given to the promotion of the health and safety of women working in the core business of mines to sustain their involvement in the mining sector.

Contribution: Practical recommendations are made to address health and safety concerns of women employed in core mining activities. These can be implemented and used by various stakeholders in the mining sector.

\section{Introduction and problem statement}

Although women all over the world have been involved in mining activities for centuries, mining has been considered a very masculine industry due to its heavily male-dominated workforce as well as the physicality of mine work. The heavily manual character of mine work together with the dirt and risk associated with mine work makes the male miner the typical labourer (LahiriDutt \& Macintyre, 2006, p. 4). In addition, the mining industry has not been an obvious career choice and preferred place of employment for women.

In South Africa, the Mineral and Petroleum Resources Development Act (No. 28 of RSA, 2002) (MPRDA) and the accompanied Broad-based Socio-economic Empowerment Charter for the South African Mining Industry (RSA, 2004) aim to rectify previous inequalities and disadvantages in the mining sector and specifically provide for the inclusion of women in core mining activities. 'Women employed in core mining activities' implies that women should hold positions equivalent to those of men, in other words, fill positions in mining that include, amongst other activities, mining, metallurgy, engineering and geology (Harmony Gold Mining Company, 2008, p. 32). They are also required to do the manual labour associated with mining (Burtenshaw, 2005). According to research conducted by the MSA Group, specialist consultants to the mining industry, approximately $11 \%$ of the South African mining industry's workforce, which includes non-core services, is represented by women (Hancock, 2014). Eftimie, Heller and Strongman (2009, p. 9) postulate that it is worldwide extremely rare to find any extractive industry companies with higher than $10 \%$ female employment, with many having less than $5 \%$. 
Although well intended, the establishment of gender equality in the male-dominant mining sector remains one of the biggest equity challenges in the country and numerous problems (such as shift work, sexual harassment, acceptance by male co-workers, physical constraints, challenges related to infrastructure facilities and pregnancy) accompany the deployment of women in core mining activities (Badenhorst, 2009; Fourie, 2009; Managing Transformation Solutions, 2011; Women in Mining Canada, 2010). Furthermore, due to women's involvement in the core business of mining, they are also exposed to the various hazards related to mine work. In addition, women face greater risks to their safety because most supportive infrastructure, such as personal protective equipment (PPE), as well as mining machinery, tools and equipment, is not designed to be used by women (Hermanus, 2007, p. 532). The safe placement of women prior to and during pregnancy remains a further challenge to mining companies (Badenhorst, 2009, p. 60).

The problem under investigation can be outlined as follows: on the one hand, mining companies are obliged to meet the requirements of the South African Mining Charter by employing $10 \%$ women in core mining positions and run the risk of losing their mining licences to operate if they do not adhere to the requirements. On the other hand, the deployment of women in the core business of mining is accompanied by various challenges, not only for management, but also for male co-workers and the women themselves. Furthermore, work in the mining sector is categorised as high-risk work and is associated with difficult working conditions; mining is one of the most physically demanding occupations (Schutte, 2011, p. 11). Therefore, it is of utmost importance that all measures be taken to ensure that the health and safety of the female mine worker are not compromised.

Against this background and problem statement, the research question to be addressed was: do mining companies in South Africa take all relevant measures (such as safeguards, protective clothing and protection during night shift and pregnancy) to ensure the health and safety of female mine workers?

\section{Purpose}

The purpose of the article is to, firstly, highlight health and safety challenges for women employed in core mining positions as identified in the literature, secondly, determine perceptions regarding the health and safety of women employed in the core business of mining according to the empirical research and, thirdly, provide recommendations that could be implemented and used by various stakeholders in the mining industry to overcome some of these challenges.

\section{Literature review}

Work in the mining sector is categorised as high-risk work and falls into the category of perceived hazardous occupations. 'Mining involves hard physical labour under conditions of extreme discomfort, deafening noise, intense heat and humidity and cramped space' (Zungu, 2011, p. 8).

The South African Mine Health and Safety Act (No. 29 of RSA, 1996b) (MHSA) enforces and promotes the health and safety of persons at work in the mining sector (p. 1). The MHSA (RSA, 1996b) was updated by the Mine Health and Safety Amendment Act (1997). The Act introduced the concepts of risk assessment and occupational health and safety management to the mining industry. Great emphasis has been placed on the reduction of mining-related deaths, injuries and diseases. Another amendment to the MHSA followed in 2008 and aimed to review and strengthen enforcement provisions, to reinforce offences and penalties and to effect certain amendments necessary to ensure consistency with other laws, particularly the MPRDA (RSA, 2002). Furthermore, the International Labour Organization's Safety and Health in Mines Convention C176 of 1995 was ratified by South Africa on 09 June 2009. It recognises the desirability of preventing any fatalities, injuries or ill health affecting workers or members of the public or damage to the environment arising from mining operations (Zungu, 2012, p. 7). The MHSA was reviewed in 2011 and 2012. In October 2013, Cabinet approved the publication of the Draft Amendment Bill of the MHSA (2013), in the Government Gazette, for public comment (SAnews, 2013). The Bill seeks to amend the MHSA (RSA, 1996b). It aims to improve the health and safety of mine employees and seeks to maintain a healthy and safe mine environment with a positive impact on environmental sustainability and resilience (SAnews, 2013).

Despite the improved efforts from the South African government, and specifically the Department of Mineral Resources, (DMR), to promote health and safety in the mining industry, the safety track record in the South African mining industry continues to be a matter of great concern to the DMR. The loss of life owing to accidents is still a concern, especially in the gold and platinum sectors (Vermeulen, 2014). According to South African Mineral Resources Minister Ngoake Ramathlodi (Vermeulen, 2014), rockfall, transport and fire-related accidents are still the major causes of death in the sector. The minister also noted that the number of occupational diseases including silicosis, noise-induced hearing loss and pulmonary tuberculosis (TB) was still excessively high. After India and China, South Africa has the third highest number of TB cases (Vermeulen, 2014). Furthermore, the DMR continues to be concerned about the health and safety of female workers in the mining industry, especially the inhumane treatment of female miners by fellow workers in some of the underground workplaces (Vermeulen, 2014).

From the above it is evident that mine health and safety challenges are still serious issues in the South African mining sector and, if left unattended, could have serious social and economic implications. Moreover, the introduction of women into the core business of mining poses new health and safety challenges to the industry. The section below 
highlights specific health and safety challenges pertaining to women working in core mining positions.

\section{Physical constraints}

Due to the physicality of mine work, many jobs require a high degree of physical strength and endurance. Some of the work tasks are difficult to perform due to the physical differences that exist between women and men (Wynn, 2001, p. 33). The gender-related differences listed below should be considered (Van Aardt, Bendeman, Christie, Gazi \& Schutte, 2008, p. 22).

Physical work capacity: Women experience significantly more physiological strain than men when performing mining tasks (Schutte, Edwards \& Milanzi, 2012, p. 3). The aerobic capacity (physical work capacity) of women is typically $15 \%-30 \%$ below the values of their male counterparts (Schutte et al., 2012, p. 3). Aerobic capacity refers to the maximal oxygen uptake that provides a quantitative measure of a person's ability to sustain highintensity physical work for longer than 5 minutes (Ashworth, Molapo, Molefe, Schutte \& Zitha, 2004, p. 34). This means that women work closer to their aerobic capacity than men and are therefore more likely to become fatigued. Fatigue is operationally defined as the 'reduced muscular ability to continue an existing effort' (Ashworth et al., 2004, p. 34). High levels of fatigue can cause reduced performance and productivity in the workplace and increase the risk of accidents and injuries occurring (Schutte, 2010, p. 54).

Mine work also requires manual handling of equipment and tools. These equipment and tools are designed to accommodate the size and strength of men (Zungu, 2011). Manual tasks can often be related to back injuries and musculoskeletal disorders in workers (Badenhorst, 2009, p. 63). In general, the manual material-handling capabilities of women are substantially lower than those of men. These differences may be attributed primarily to differences in muscle strength (Ashworth et al., 2004, p. 34). Women only have $55 \%$ of men's upper-body strength and $72 \%$ of their lower-body or leg strength (Van Aardt et al., 2008, p. 22). On average, a woman's lifting strength is $60 \%-70 \%$ of that of a man (Ashworth et al., 2004, p. 34).

Heat tolerance: Women working on mines, and in particular underground, are also exposed to extreme heat. Singer (2002, p. 1) states that the underground environment can be defined as dark and damp, and with an increase in temperature relative to an increase in depth. In South African mines, work environments with a wet-bulb temperature higher than $27.4{ }^{\circ} \mathrm{C}$ are considered hot and necessitate the introduction of practices to safeguard miners (Schutte, 2009). According to Ashworth et al. (2004, p. 35), all employees who work under 'conditions conducive to heat stroke' should be screened for gross or permanent heat intolerance by means of the standard heat tolerance screening test procedure. Heat tolerance screening is done to assess whether an individual can withstand high temperatures whilst doing physically demanding work, with the aim of protecting individuals against the negative consequences of heat exposure, such as heat stroke and heat-related diseases (Benya, 2009, p. 56).

Van Aardt et al. (2008, p. 22) postulate that under conditions of high ambient temperature, thermoregulation in women is less efficient than in men. This is also confirmed by the findings of Schutte (as cited in Van Aardt et al., 2008, p. 22), which indicate that female mine workers are less tolerant to heat than their male counterparts.

High occupational heat loads can lead to the following problems, amongst others: impaired work capacity, errors of judgement with obvious implications for safety, lethargy and fatigue and complications such as heat stress, which can lead to heat stroke, which is often fatal (Schutte, 2009, p. 1). The following personal risk factors, amongst others, may reduce an individual's tolerance for heat stress: age, obesity, state of hydration, use of medication and drugs, gender and acclimatisation state (Zungu, 2011). Furthermore, gynaecological conditions and pregnancy could also affect the way in which women handle heat stress (Zungu, 2011).

Anthropometry and body composition: According to Van Aardt et al. (2008, p. 22), differences exist in the anthropometry and body composition of men and women. The average man is heavier and has a greater lean body mass than the average woman. Furthermore, women tend to have more body fat and less lean mass than their male counterparts. Therefore, women will have lower maximum oxygen uptake values to transport the same body mass.

The design of mining equipment and tools used during mining does not always take into account the anthropometry of the user population (Van Aardt et al., 2008, p. 22). Much of the mining equipment used in South African mines is designed to fit men (Badenhorst, 2009, p. 62). When mines started to recruit women, mining equipment was still only suitable for men, but both women and men had to share such equipment. Body dimensions are an important concept that should be taken into consideration with the design of mining equipment as well as its efficient operation (Campbell, 2007). Women face great risks to their safety when using work equipment, machinery and tools designed for men, and this may contribute to women's work accident risks (Badenhorst, 2009, p. 63; Hermanus, 2007, p. 532; Van Aardt et al., 2008, p. 23).

According to Badenhorst (2009, p. 59), a female employee can do any job that she is qualified to do, provided that she meets the requirements of the specific job. Furthermore, an employee should not be employed in a job or conduct tasks for which they are not medically fit or if they do not have the required physical and functional capabilities. Emphasis should be placed on worker selection, paying attention to the ergonomic fit of equipment, work tools and tasks to the worker's physique (Van Aardt et al., 2008, p. 23). A programme should be established to ensure that minimum medical requirements are met by employees, which include health risk assessment or a health risk 
TABLE 1: Distribution and response count per mine.

\begin{tabular}{|c|c|c|c|c|c|c|c|c|}
\hline \multirow[t]{2}{*}{ Mine commodity } & \multicolumn{2}{|c|}{ Management } & \multicolumn{2}{|c|}{$\begin{array}{l}\text { Female employees working in core } \\
\text { mining activities }\end{array}$} & \multicolumn{2}{|c|}{$\begin{array}{l}\text { Male employees working in core } \\
\text { mining activities }\end{array}$} & \multirow[t]{2}{*}{$\begin{array}{l}\text { Total distribution } \\
\text { count }\end{array}$} & \multirow[t]{2}{*}{$\begin{array}{l}\text { Total response } \\
\text { count }\end{array}$} \\
\hline & $\begin{array}{l}\text { Distribution } \\
\text { count }\end{array}$ & $\begin{array}{c}\text { Response } \\
\text { count }\end{array}$ & Distribution count & $\begin{array}{l}\text { Response } \\
\text { count }\end{array}$ & Distribution count & $\begin{array}{l}\text { Response } \\
\text { count }\end{array}$ & & \\
\hline Copper mine & 30 & 17 & 60 & 34 & 60 & 17 & 150 & 68 \\
\hline Phosphate mine & 30 & 12 & 50 & 21 & 50 & 17 & 130 & 50 \\
\hline Platinum mine & 40 & 0 & $180(15 \times 12$ shafts $)$ & 22 & $180(15 \times 12$ shafts $)$ & 16 & 400 & 38 \\
\hline Total participants & 100 & 29 & 290 & 77 & 290 & 50 & 680 & 156 \\
\hline
\end{tabular}

profile for each occupation and the establishment of medical standards for each of these occupations based on the risk profiles (Badenhorst, 2009, p. 70). Furthermore, a test battery to conduct and measure these abilities should be established (Badenhorst, 2009, p. 70).

\section{Pregnancy challenges}

Pregnancy and breastfeeding are two of the major challenges mining companies have to deal with when incorporating women into the mining workforce. Pregnant employees are strongly protected under South African legislation. The Constitution of South Africa (RSA, 1996a), Section 9(3), and the Employment Equity Act (EEA, RSA, 1998), Section 6, explicitly prohibit unfair discrimination against anyone or any employee on the grounds of pregnancy. Furthermore, the Basic Conditions of Employment Act (BCEA, RSA, 1997) forbids employers to require a pregnant employee or an employee who is nursing her child to perform work that is hazardous to her health or the health of her child. It also obliges employers to offer her suitable, alternative employment if the employee is required to perform night work or if her work poses a danger to her health or safety or that of her child. In addition, the Code of Good Practice on the Protection of Employees during Pregnancy and after the Birth of a Child (Israelstam, 2012) aims at protecting pregnant and postpregnant employees.

If a woman falls pregnant, the onus rests on her to inform management of her pregnancy in order to immediately enable them to accommodate her in a safe position (Van Aardt et al., 2008, p. 23). Most women can continue working during pregnancy; however, the nature of the job and the risks associated with the job will determine for how long she will be able to perform the specific requirements of the job. Exposure to physical, chemical, ergonomic and biological hazards must be considered potentially dangerous to the health of pregnant women (Badenhorst, 2009, p. 69). Risk assessment is fundamental to the safe placement of female employees during pregnancy (Badenhorst, 2009, p. 60).

\section{Personal protective equipment challenges}

Because the mining industry was historically viewed as a 'man's world', PPE was designed with men in mind. The design of most of the PPE used at South African mines is based on the anthropometry of male populations from Germany, France and the USA (Van Aardt et al., 2008, p. 23). On average, women's feet are shorter and narrower than men's, their bodies are shorter in length, their shoulders are narrower and their hips are usually wider (Zungu,
2011). The lack of correctly fitting PPE can affect the way women are protected as well as the way in which they are able to perform their jobs. Ill-fitting PPE restricts the ability of employees to move easily and exposes them to environmental hazards associated with mining. As women differ from men in terms of size and shape, their PPE should be adjusted and developed to ensure a proper fit, comfort and protection (Badenhorst, 2009, p. 62).

From the literature review it is clear that various factors need to be considered to ensure the health and safety of women working in the core business of mines. Consequently, the empirical findings of the research are presented.

\section{Method \\ Research approach}

A mixed method research design was followed by applying a quantitative and qualitative research approach.

\section{Measures}

\section{Research participants}

The research setting was limited to the following three mines: a copper mine (underground), a phosphate mine (open-cast) and a platinum mine (underground). The mines were selected on an availability basis (convenience sampling). Convenience sampling refers to sampling by obtaining people or units that are conveniently available (Zikmund, Babin, Carr \& Griffin, 2010, p. 396).

For the purpose of quantitative research, the study population consisted of management as well as male and female employees working in core mining activities of the three mines. Convenience sampling was used to select the participants. In total, 156 responses were received: 68 from the copper mine, 50 from the phosphate mine and 38 from the platinum mine (see Table 1).

Purposive or judgemental sampling was used to select participants for the qualitative research. Purposive sampling is a type of non-probability sampling in which the units to be observed are selected on the basis of the researcher's judgement about which ones will be the most useful or representative (Babbie \& Mouton, 2011, p. 184). In total, 12 individual interviews and 19 group interviews (69 participants) were conducted. The researcher aimed to gain information from various operations; therefore, the participants selected varied from various categories of employment and mining disciplines (see Table 2). 


\section{Measuring instruments}

Quantitative data were collected by means of a structured questionnaire. Qualitative data were collected by means of individual and group interviews. The interviews were conducted in English. The interviews were semi-structured, as an interview guide was utilised. Data collected by means of semi-structured and group interviews were audio and video recorded and written notes were taken.

The qualitative approach supported the quantitative approach and aimed to provide more reliable results, because the researcher could ask probing questions of the participants and by so doing avoid misunderstanding of questions and gain better insight into the phenomenon of interest, as recommended by Welman, Kruger and Mitchell (2010, p. 167). In addition, the researcher could gain a deep understanding of the variables that have an impact on women in the mining sector.

\section{Research procedure}

The researcher formally requested permission from mine management to conduct research at three mining companies. After permission was granted, a formal appointment was scheduled with mine management to explain the nature and extent of the research. In each research setting (mines), a contact person (human resource officer targeted with women in mining) was allocated to the researcher to provide the necessary assistance and support during the research, which included the following: distributing and collecting the quantitative questionnaires, selecting appropriate participants for the individual interviews as well as group interviews, scheduling interviews and organising

TABLE 2: Individual and group interviews conducted at the mines.

\begin{tabular}{|c|c|c|c|}
\hline Interviews & Groups & Job specification & Gender \\
\hline \multicolumn{4}{|l|}{ Copper mine } \\
\hline \multirow[t]{13}{*}{ Individual } & & Manager: Employee relations & Male \\
\hline & & Employment equity coordinator & Male \\
\hline & & Ventilation technician (Underground) & Female \\
\hline & & Instrument technician (Underground) & Female \\
\hline & & Instrument technician (Underground) & Male \\
\hline & & Instrument technician (Underground) & Male \\
\hline & - & Development dispatch (Underground) & Female \\
\hline & - & Fitter and turner (Concentrator) & Female \\
\hline & & Electrical superintendent (Concentrator) & Female \\
\hline & & Reverb operator (Smelter) & Female \\
\hline & & Electrician (Smelter) & Female \\
\hline & & Superintendent internal audit (Administration) & Female \\
\hline & & Medical doctor & Female \\
\hline \multirow[t]{13}{*}{ Group interviews } & Group 1 & Senior geologists (Underground) & Female \\
\hline & & Strata control officers (Underground) & \\
\hline & Group 2 & Dump truck operators (Surface mining) & Female \\
\hline & & Multi-skill operators (Surface mining) & \\
\hline & & Laboratory assistants (Surface mining) & \\
\hline & & Laboratory supervisors (Surface mining) & \\
\hline & Group 3 & Engineers in training (Refinery) & Female \\
\hline & & Operators (Refinery) & \\
\hline & & Nickel and dispatch superintendent (Refinery) & \\
\hline & Group 4 & Women in Mining Forum (Meeting) & Female \\
\hline & Group 5 & Human resource officers & Male \\
\hline & Group 6 & Supervisors (Underground) & Male \\
\hline & & Supervisors (Refinery) & \\
\hline \multicolumn{4}{|l|}{ Phosphate mine } \\
\hline \multirow[t]{11}{*}{ Group interviews } & Group 1 & Finance manager (Male) & Female/Male \\
\hline & & Procurement manager (Female) & \\
\hline & & Human resource manager (Female) & \\
\hline & & Group human capital manager (Male) & \\
\hline & Group 2 & Plant operators & Male \\
\hline & Group 3 & Attendants flotation & Male \\
\hline & & Laboratory attendants & \\
\hline & Group 4 & Operators operations & Female \\
\hline & & Attendant sample preparer & \\
\hline & & Lab attendants & \\
\hline & & Attendants bush pumps and fitters & \\
\hline
\end{tabular}


TABLE 2 (Continues...): Individual and group interviews conducted the mines.

\begin{tabular}{|c|c|c|c|}
\hline Interviews & Groups & Job specification & Gender \\
\hline \multicolumn{4}{|l|}{ Platinum mine } \\
\hline \multirow[t]{27}{*}{ Group interviews } & Shaft A & General workers (Underground) & Female \\
\hline & & Loco operator (Underground) & \\
\hline & Shaft A & Team leader: Haulage maintenance (Underground) & Male \\
\hline & & Production supervisor (Underground) & \\
\hline & & Construction gang: Supervisor (Underground) & \\
\hline & & Rail maintenance (Underground) & \\
\hline & & General: Haulage maintenance (Underground) & \\
\hline & Shaft B & Learner rock breakers (Underground) & Female \\
\hline & & Team workers (Underground) & \\
\hline & & Production clerk (Underground) & \\
\hline & Shaft B & Mining clerks (Surface) & Male \\
\hline & & Team leaders (Underground) & \\
\hline & & Electrical assistants (Underground) & \\
\hline & & Loco operators (Underground) & \\
\hline & & Production crew (Underground) & \\
\hline & Shaft D & Electrical foremen & Male \\
\hline & & Storemen & \\
\hline & Shaft D & Diesel bay attendants & Female \\
\hline & & Dozer operators & \\
\hline & & Pecker operators & \\
\hline & Shaft $E$ & Service crew & Male \\
\hline & & Winch operators & \\
\hline & & Development crew & \\
\hline & Shaft $E$ & Service crew & Female \\
\hline & & $\begin{array}{l}\text { Cleaners (formerly employed underground but was injured, now working on } \\
\text { surface) }\end{array}$ & \\
\hline & & Belt attendants & \\
\hline & & Rigger artisans & \\
\hline
\end{tabular}

underground field trips as well as visits to surface mining operations. Most of the individual interviews and group interviews were scheduled between shifts in order not to interfere with the work responsibilities of the participants. Ethical considerations, such as voluntary participation, informed consent, privacy, anonymity and confidentiality were taken into account whilst conducting the research, as recommended by Babbie and Mouton (2011, p. 520).

\section{Data analysis}

Quantitative data obtained through the questionnaires were analysed with the support and assistance of the Statistic Consultation Service of North-West University. The statistical software program SPSS 21.0 for Windows was used to analyse the data. Firstly, descriptive statistics are presented, differentially in terms of the three mines included in the study. Descriptive statistics were reported per statement as mean. The benchmark (ideal) in terms of responses for every statement is 4 , which indicates that compliance with the specific statement is satisfactory, except for a small number of reversed statements. Ratings of 2.5 and lower were regarded as 'low' and indicate that compliance with the specific statement is none or very limited. The opposite is applicable to reversed statements. Secondly, a factor analysis was conducted to explore the factorial structure of the section. The following values were measured and the results are reported as part of the factor analysis: the Kaiser-MeyerOlkin (KMO) measure of sampling adequacy, the $p$-value of
Bartlett's test of sphericity, pattern matrices, communalities, Cronbach's alpha coefficients and factor means. Thirdly, effect sizes were measured. Because an availability sample was used, $p$-values were not relevant and differences between means were examined for practical significance with effect sizes. Lastly, qualitative data obtained through the semistructured interviews and group interviews were analysed by means of conceptual (thematic) analysis. Coding choices were made according to the following eight category coding steps indicated by Palmquist (cited in Babbie \& Mouton, 2011, p. 492): deciding on the level of analysis, deciding on how many concepts to code for, deciding whether to code for the existence or frequency of a concept, deciding how to distinguish between concepts, developing rules for the coding of texts, deciding what to do with the data that are irrelevant, coding the data and analysing the results.

\section{Results \\ Descriptive statistics}

Similar results were obtained for almost all the different indicators across all three mines (see Table 3). Almost all the indicators calculated a mean of above 2.5 across all three target groups of the three mines, indicating that compliance with these statements is satisfactory. The only negative responses were reported for the following indicator statements:

- It is safe for women to work the night shift. This statement calculated a mean below 2.5 for the female research 
TABLE 3: Participants' perceptions regarding health and safety in the workplace.

\begin{tabular}{|c|c|c|c|c|c|c|c|c|c|}
\hline \multirow[t]{2}{*}{ Number } & \multirow[t]{2}{*}{ Indicator statement } & \multicolumn{3}{|c|}{ Copper mine } & \multicolumn{3}{|c|}{ Phosphate mine } & \multicolumn{2}{|c|}{ Platinum mine } \\
\hline & & $\begin{array}{l}\text { Male in } \\
\text { core }\end{array}$ & $\begin{array}{l}\text { Female in } \\
\text { core }\end{array}$ & Management & $\begin{array}{l}\text { Male in } \\
\text { core }\end{array}$ & $\begin{array}{l}\text { Female in } \\
\text { core }\end{array}$ & Management & $\begin{array}{l}\text { Male in } \\
\text { core }\end{array}$ & $\begin{array}{l}\text { Female } \\
\text { in core }\end{array}$ \\
\hline 1 & I/Women feel safe at work & 2.94 & 3.15 & 3.00 & 3 & 2.9 & 3.08 & 3.13 & 3.09 \\
\hline 2 & $\begin{array}{l}\text { It is dangerous for women to work underground } \\
\text { in the mining company }\end{array}$ & 2.29 & 2.12 & 2.00 & 2.15 & 2.47 & 1.71 & 1.81 & 2.09 \\
\hline 3 & It is safe for women to work the night shift & 3.18 & 2.72 & 3.06 & 2.93 & 2.35 & 3.17 & 2.64 & 2.4 \\
\hline 4 & $\begin{array}{l}\text { The safeguards (protective clothing, masks, etc.) } \\
\text { provided by the company are adequate }\end{array}$ & 3.47 & 2.97 & 3.19 & 3.29 & 2.95 & 3.33 & 2.87 & 2.86 \\
\hline 5 & $\begin{array}{l}\text { Protective clothing that women are obliged to } \\
\text { wear is woman-friendly, in other words, designed } \\
\text { keeping women in mind }\end{array}$ & 3.24 & 2.73 & 3.00 & 2.76 & 2.7 & 3.33 & 2.67 & 2.65 \\
\hline 6 & $\begin{array}{l}\text { Pregnant women are provided with alternative } \\
\text { employment where they are not exposed to } \\
\text { hazardous or dangerous circumstances }\end{array}$ & 3.35 & 3.25 & 3.38 & 3.00 & 3.00 & 2.92 & 3.2 & 3.09 \\
\hline 7 & $\begin{array}{l}\text { Alternative employment is provided for women } \\
\text { during early motherhood and breastfeeding }\end{array}$ & 3.06 & 2.44 & 2.69 & 3.00 & 2.74 & 2.45 & 3.27 & 3.05 \\
\hline 8 & $\begin{array}{l}\text { The mining company is actively involved in HIV/ } \\
\text { AIDS-awareness programmes }\end{array}$ & 3.65 & 3.65 & 3.56 & 3.69 & 3.48 & 3.67 & 3.4 & 3.43 \\
\hline 9 & $\begin{array}{l}\text { The mining company works to mitigate and } \\
\text { combat HIV/AIDS in the mining industry }\end{array}$ & 3.53 & 3.38 & 3.56 & 3.38 & 3.24 & 3.58 & 3.33 & 3.15 \\
\hline 10 & $\begin{array}{l}\text { The mining company makes provision for } \\
\text { rehabilitation in case of accidents at work }\end{array}$ & 3.41 & 2.91 & 3.44 & 3.12 & 3.19 & 3.55 & 3.00 & 3.00 \\
\hline
\end{tabular}

Note: Mean scores of 2.5 and lower (2.5 and above for reversed statements) were regarded as 'low' and indicate that compliance with the specific statement is none or very limited.

TABLE 4: Kaiser-Meyer-Olkin and Bartlett's test of sphericity.

\begin{tabular}{lc}
\hline Kaiser-Meyer-Olkin & Value \\
\hline$p$-value of Bartlett's test of sphericity & 0.650 \\
Approximate chi-square & 243.933 \\
$d f$ & 45 \\
Significance & 0.000 \\
\hline
\end{tabular}

participants of the phosphate $($ mean $=2.35)$ and platinum (mean $=2.4)$ mines.

- Alternative employment is provided for women during early motherhood and breastfeeding. This statement calculated a mean below 2.5 for the female research participants of the copper mine $($ mean $=2.44)$ and the management research participants of the phosphate mine $($ mean $=2.4)$.

\section{Factor analysis}

A factor analysis was conducted on the 10 statements listed in the questionnaire. The results of the KMO and Bartlett's test of sphericity are presented in Table 4.

The KMO measured 0.650 and indicates that the sample size is still adequate for factor analysis. According to Field (2005, p. 640), factor analysis is inappropriate for values smaller than 0.5; however, values between 0.5 and 0.7 are regarded as mediocre. The $p$-value of Bartlett's test of sphericity returned a value less than 0.05 , suggesting that the correlation between statements is sufficient for factor analysis (Field, 2005, p. 652). The results for the factor analysis are reported in Table 5.

Four factors (Work environment, Motherhood, HIV/AIDS programme, Personal protection) were extracted by Kaiser's criteria (Field, 2005, p. 652) to explain $67.50 \%$ of the total variance, in the section on Health and safety in the workplace. The statements all loaded above 0.3 on the four identified factors. The factor means were calculated to be above 2.5, which indicates a tendency to agree with the statements contained in the identified factors.
The Work environment factor as well as the Motherhood factor has a Cronbach's alpha coefficient of 0.51, which could be regarded as a relatively low reliability. This was probably caused by the low number of statements in the factors (Field, 2009, p. 675). The HIV/AIDS programme factor has a Cronbach's alpha coefficient of 0.79 , which is above the required 0.7 and shows high reliability and internal consistency. The Personal protection factor has a Cronbach's alpha coefficient of 0.61 , which could be regarded as an accepted reliability (Field, 2009, p. 675).

\section{Factor correlation matrix}

The Pearson correlations between the extracted factors for the section Health and safety in the workplace are reported in Table 6.

Factor 1 and factor 2 have a correlation coefficient smaller than 0.3 , whilst factor 3 and factor 4 have a correlation coefficient greater than 0.3 , indicating that there is a strong relationship between HIV/AIDS programme and Personal protection. However, Factor 1 has a small correlation with factors 2, 3 and 4. A small correlation also exists between Factor 2 and factors 3 and 4 .

\section{Comparison of the three target groups of the different mines regarding health and safety in the workplace}

The descriptive statistics together with effect sizes of the different target groups regarding the section Health and safety in the workplace are reported in Table 7.

The effect sizes for the factors Work environment, Motherhood and HIV/AIDS programme indicated that the difference between the means of the different target groups is not practically significant, with the exception of the female versus male target groups of the copper mine (Motherhood factor) and the female versus management target groups of the phosphate mine (HIV/AIDS programme), for which 
TABLE 5: Pattern matrix $\dagger$ of health and safety in the workplace.

\begin{tabular}{|c|c|c|c|c|c|}
\hline Question statement & $\begin{array}{l}\text { Factor } 1 \text { : Work } \\
\text { environment }\end{array}$ & $\begin{array}{l}\text { Factor 2: } \\
\text { Motherhood }\end{array}$ & $\begin{array}{l}\text { Factor 3: HIV/AIDS } \\
\text { programme }\end{array}$ & $\begin{array}{l}\text { Factor 4: Personal } \\
\text { protection }\end{array}$ & Communalities \\
\hline It is dangerous for women to work underground in the mining company ${ }^{\circledast}$ & -0.891 & - & - & - & 0.759 \\
\hline I feel safe at work & 0.389 & - & - & - & 0.551 \\
\hline $\begin{array}{l}\text { The mining company makes provision for rehabilitation in case of accidents } \\
\text { at work }\end{array}$ & 0.427 & - & - & - & 0.623 \\
\hline $\begin{array}{l}\text { Alternative employment is provided for women during early motherhood } \\
\text { and breastfeeding }\end{array}$ & - & 0.809 & - & - & 0.679 \\
\hline $\begin{array}{l}\text { Pregnant women are provided with alternative employment where they are } \\
\text { not exposed to hazardous or dangerous circumstances }\end{array}$ & - & 0.686 & - & - & 0.657 \\
\hline The mining company is actively involved in HIV/AIDS-awareness programmes & - & - & 0.935 & - & 0.85 \\
\hline $\begin{array}{l}\text { The mining company works to mitigate and combat HIV/AIDS in the mining } \\
\text { industry }\end{array}$ & - & - & 0.856 & - & 0.725 \\
\hline $\begin{array}{l}\text { Protective clothing that women are obliged to wear is woman-friendly, in } \\
\text { other words, designed keeping women in mind }\end{array}$ & - & - & - & 0.827 & 0.75 \\
\hline $\begin{array}{l}\text { The safeguards (protective clothing, masks, etc.) provided by the company } \\
\text { are adequate }\end{array}$ & - & - & - & 0.718 & 0.634 \\
\hline It is safe for women to work the night shift & - & - & - & 0.651 & 0.522 \\
\hline Factor mean & 2.78 & 3.00 & 3.45 & 2.83 & - \\
\hline Factor standard deviation & 0.41 & 0.67 & 0.54 & 0.64 & - \\
\hline
\end{tabular}

, Reversed statement.

TABLE 6: Factor correlation matrix.

\begin{tabular}{|c|c|c|c|c|c|}
\hline Number & Factors: Health and safety in the workplace & 1 & 2 & 3 & 4 \\
\hline 1 & Factor 1: Work environment & 1.000 & -0.025 & 0.173 & 0.200 \\
\hline 2 & Factor 2: Motherhood & -0.025 & 1.000 & 0.146 & 0.142 \\
\hline 3 & Factor 3: HIV/AIDS programme & 0.173 & 0.146 & 1.000 & 0.322 \\
\hline 4 & Factor 4: Personal protection & 0.200 & 0.142 & 0.322 & 1.000 \\
\hline
\end{tabular}

TABLE 7: Comparison of the three target groups of the different mines regarding health and safety in the workplace.

\begin{tabular}{|c|c|c|c|c|c|c|c|c|c|}
\hline \multirow[t]{2}{*}{ Factor } & \multirow[t]{2}{*}{ Mine } & \multicolumn{2}{|c|}{ Men } & \multicolumn{2}{|c|}{ Women } & \multicolumn{2}{|c|}{ Management } & \multicolumn{2}{|c|}{ Effect sizes } \\
\hline & & Mean & SD & Mean & SD & Mean & SD & $\begin{array}{c}\text { Women versus } \\
\text { Men }\end{array}$ & $\begin{array}{l}\text { Women versus } \\
\text { Management }\end{array}$ \\
\hline \multirow[t]{2}{*}{ Factor 1: Work environment } & Phosphate & 2.81 & 0.31 & 2.90 & 0.49 & 2.99 & 0.46 & -0.19 & 0.17 \\
\hline & Platinum & 2.61 & 0.50 & 2.73 & 0.43 & - & - & -0.23 & - \\
\hline \multirow[t]{2}{*}{ Factor 2: Motherhood } & Phosphate & 3.00 & 0.42 & 2.88 & 0.76 & 2.71 & 0.54 & 0.16 & -0.22 \\
\hline & Copper & 3.21 & 0.64 & 2.84 & 0.65 & 3.03 & 0.53 & $0.55 \dagger$ & 0.29 \\
\hline \multirow[t]{3}{*}{ Factor 3: HIV/AIDS programme } & Phosphate & 3.53 & 0.43 & 3.36 & 0.53 & 3.63 & 0.48 & 0.33 & $0.51 \dagger$ \\
\hline & Copper & 3.59 & 0.48 & 3.53 & 0.46 & 3.56 & 0.51 & 0.12 & 0.06 \\
\hline & Platinum & 3.34 & 0.75 & 3.28 & 0.62 & - & - & 0.09 & - \\
\hline \multirow[t]{3}{*}{ Factor 4: Personal protection } & Phosphate & 2.97 & 0.39 & 2.67 & 0.77 & 3.28 & 0.49 & 0.39 & $0.79 \ddagger$ \\
\hline & Copper & 3.29 & 0.51 & 2.79 & 0.59 & 3.08 & 0.54 & $0.84 \ddagger$ & $0.49 \dagger$ \\
\hline & Platinum & 2.75 & 0.59 & 2.63 & 0.73 & - & - & 0.17 & - \\
\hline
\end{tabular}

SD, Standard deviation.

$\dagger$, medium effect: $d=0.5 ;$, large effect: $d=0.8$.

the d-values indicate a medium effect. It could therefore be deduced that on average, the male target group of the copper mine is more in agreement with the statements contained in the Motherhood factor than the female target group themselves. Furthermore, the management target group of the phosphate mine is more in agreement with HIV/AIDS programme than the female target group themselves. A large effect is evident from the female versus male target groups of the copper mine and the female versus management target groups of the phosphate mine for the Personal protection factor, indicating that on average, the participants from the male and management target groups of the copper mine as well as the management target group of the phosphate mine are more in agreement with Personal protection than the female target group themselves.

\section{Health and safety concerns regarding women working in core mining positions}

This section presents the findings of the qualitative inquiry. Although the participants indicated that the mines take all measures to ensure a safe environment and, in general, they do feel safe at work, some concerns were raised, which are discussed next.

\section{Physical ability}

Although the female participants indicated that they have the physical ability to do their jobs well, they indicated that the work is tough and not easy to perform, especially underground. The women stated that they do not always have the physical strength, power and stamina required 
for specific positions. They want to prove themselves and often neglect their bodies to do their jobs well. The following quotes provide an indication of the female participants' opinions regarding the physical ability of women employed in core mining positions and the constraints experienced:

'I don't have the steam to work at the position that I am working at.' 'I am not strong enough.' 'The job of mine is too hard.' 'We are sweating underground.' (Female general, interview, 2011)

'The loco is like a train, nè? It's hard to operate. The steering wheel and everything is hard. The brakes. And to be on it every day, yô, it is hard. When you go on period you have some pains. Your back it pains. And that thing, it vibrates. I'm on it eight hours every day'. (Female loco operator, interview, 2011)

\section{Personal protective equipment}

It is evident that some mining companies still provide overalls (shirts and trousers), shoes and gloves that are not women-friendly and are designed with men in mind. Moreover, some female participants were not satisfied with the respirators provided at one of the mines included in the study. The following responses reflect women's need for protective clothing that are designed with women in mind:

'Women, you know, have got curves and we are wearing men's clothes. Sometimes it is difficult for you to know the correct size. Because it is male size, you find when you order overalls they are too big. When you order the small it is too small.' (Female lab attendant, interview, 2011)

'I'm not satisfied with the respirator that is provided to use in the plant. It sometimes feels [as if] I cannot inhale enough oxygen.' (Female electrician, interview, 2011)

\section{Pregnancy}

From the interviews and focus group discussions it became clear that different views exist on female employees' experiences regarding treatment by management of the various mining companies during and after pregnancy (early motherhood and breastfeeding). The data also show that treatment within the same mining company differs. Some of the participants indicated that they were treated well from the moment they disclosed their pregnancies and they were employed in alternative positions that require light duty. Others indicated that they were not treated well at all and were not given light duty; they had to ask to be moved to work on the surface. The following quote expresses the opinion of a participant that was not treated well during her pregnancy:

'The mine did not accommodate me when I fell pregnant. I went through hell. There are 21 men and I'm the only woman. I used to be ordered to work where it was not even safe. There is a lot of gas and dust. While I was pregnant no one ever considered that I was. I told my supervisor and everybody knew up to the manager that I was pregnant. From the very first month I was pregnant, the first trimester is the most difficult time of pregnancy, I was ordered "to go to hell and back". That was when it was very much tough. I fainted the other day when they forced me to work and I told them that I'm not feeling great today.' (Female reverb operator, interview, 2011)
According to the participants from the management target group of the copper and phosphate mines, women are removed from working conditions that could have an effect on their pregnancies, for example underground and areas with X-ray machines and related radioactivity. Provisions are made for female employees as per the MHSA.

\section{Dust}

Dust was indicated as a main concern amongst the participants. According to the female participants, dust affects their lungs, eyes and ears. The male participants indicated that women often get a rash from working in dusty areas and sometimes they need to take the next working day off to recover. The female participants felt that the mining company could do more to reduce dust in the work environment. They suggested that dust masks be improved and that water be used to reduce dust in dusty work environments.

\section{Vibration}

The female participants indicated that work environments entailing vibration as well as the operating of heavy vibrating equipment and machines, such as locomotives, winding engines, rubber dozers and dump trucks, are not good for women, even if they are not pregnant. It was indicated that vibrating equipment tends to affect their menstruation cycles. Furthermore, it was indicated that vibration during pregnancy could enhance miscarriages.

\section{High risk for accidents}

As indicated in the introduction, the mining industry is a high-risk work environment. Women are not used to the dangerous work environment and often get scared when accidents occur. The following quotation provides an indication of the participant's perceptions of mining as a dangerous environment:

'As women we are very scared. Maybe sometimes you think maybe the rock will fall down. ... Even the cage, just to go down. I remember the first time, I was crying. Sometimes the cage get stuck with you in the air for 20 minutes or 40 minutes. Just hanging there. Not knowing whether you are going to ... go down or go up.' (Female loco operator, interview, 2011)

\section{Night shift}

Some female participants indicated that they do not feel safe when working night shifts. Sometimes only one or two women are working with many men during night shifts. Although security services are present at the main gates, a need was voiced for more security in each section or shaft. A need was also detected to lighten up areas that are dark at night.

\section{Discussion Outline of the results}

The quantitative responses showed mainly positive results, as on average, the participants across all three mines agreed with the statements contained in the identified four factors: the Work environment factor, the Motherhood factor, the HIV/ 
AIDS programme factor and the Personal protection factor. It can therefore be deduced that, on average, the participants are satisfied with the way the mining companies included in the study apply and implement health and safety measures in the workplace. However, it should be noted that the female research participants of the phosphate and platinum mines indicated concerns regarding their safety when working the night shift. This is also reinforced by the findings of the qualitative inquiry. Furthermore, the female research participants of the copper mine voiced serious concerns regarding alternative employment provided for women during early motherhood and breastfeeding. The same sentiment was also shared by the management participants of the phosphate mine. As indicated in the literature review, pregnant employees are strongly protected under South African legislation, including the Constitution of South Africa (RSA, 1996a), Section 9(3), the EEA (RSA, 1998), Section 6 and the BCEA (RSA, 1997), sections 25 and 26. In addition, the Code of Good Practice on the Protection of Employees during Pregnancy and after the Birth of a Child provides guidelines to employers on how to protect pregnant and post-pregnant employees. Employers should abide by the requirements of the mentioned legislation.

Although positive responses were obtained from the quantitative results for the Personal protection factor, the qualitative findings revealed deficiencies and limitations in this regard. It is evident that some mining companies still provide overalls (shirts and trousers), shoes and gloves that are not women-friendly and are designed with men in mind. Research conducted by Zungu (2012, p. 10) also revealed challenges related to the size and fitting of PPE used by female miners. The female body differs from the male body; therefore, overalls, shoes and gloves designed for men do not secure a perfect and comfortable fit, which could compromise the health and safety of the female employee, as also indicated in the literature review. The South African Mine Health and Safety Council also showed its commitment to the safety of women working in the core business of mining by conducting research on PPE issues. The main recommendations stemming from the research include the following: to set minimum standards for providing undergarments for female workers, to set minimum standards for compliance in terms of the provision of PPE for women in mining and to conduct an additional study to facilitate the design of such PPE, as the industry does not currently design PPE for women in mining (Chamber of Mines of South Africa, 2012, p. 4).

It is also evident from the qualitative findings that some women experience extreme difficulties in performing mine work that requires physical strength and stamina. This is also in line with the findings of the literature review, which suggest that gender differences exist with regard to physical work capacity, heat tolerance and anthropometry and body composition. Therefore, it is not surprising that women often experience significantly more physiological strain than men when performing strenuous physically demanding mining tasks. It is of utmost importance to only employ a woman if she is qualified to do the job, if she meets the requirements (physical and functional capabilities) of that specific job and if she is medically fit for the job (Badenhorst, 2009, p. 59), so as not to compromise the health and safety of the female employee.

From the research it is evident that the introduction of women in the core business of mining requires commitment and devotion from management and the relevant state departments. Moreover, the health and safety of female employees require, amongst others, exceptional attention to the provision of women-friendly PPE, considerations relating to worker selection and the ergonomic fit of equipment, work tools and tasks to the worker's physique. Safety, health and wellness are the responsibility of managers; they should ensure that employees are not unnecessarily endangered and that workers are fully aware of and properly trained and prepared for unusual workplace risks (Nel et al., 2011, p. 283).

\section{Practical implications}

Although the mining companies have improved their efforts to promote health and safety in the workplace, the health and safety of mine workers remain a major challenge. A holistic approach to risk management, which includes consideration of gender implications and ergonomic factors, is needed if the participation of women is to be sustained in mining.

\section{Limitations}

A limitation to the study lies in the accessibility of the mining sector as a research setting. Past research has shown that it is sometimes extremely difficult to interview employees and representatives of mining companies and to get their members to fill in questionnaires. It was not an easy task to gain access to the mining companies. Several visits and correspondence took place before permission was granted for the research. In addition, the platinum mine experienced many difficulties and labour unrest during the time the research was conducted. Because of that, several interviews with management were postponed and eventually cancelled. Despite numerous attempts from the researcher, no quantitative responses (questionnaires) were received from the management target group of the platinum mine. Furthermore, not all participants targeted for the semi-structured interviews and group interviews turned up for the meetings. Some of the participants could not stay for the duration of the interviews due to work responsibilities and emergencies. Others were drained and tired after shift work and wanted to depart for home as soon as possible to get some rest and take care of their family responsibilities before the start of their next shift. The researcher made use of existing skills, knowledge and networks (such as the study promoter, who has worked extensively in this field, and the Bench Marks Foundation) to overcome some of these problems.

\section{Recommendations}

From the literature review and the empirical findings it is evident that specific attention should be given to the 
promotion of the health and safety of women working in mines. The following recommendations, informed by the literature review and empirical findings, are made to address health and safety concerns of women employed in core mining activities and to contribute to the sustainable deployment of women in the mining sector:

- It is evident that women have unique needs in terms of PPE provided. Ill-fitting PPE can affect the way women are protected as well as the way in which they are able to perform their jobs. Therefore, PPE needs to be designed and developed with women in mind to ensure a proper fit and not compromise the health and safety of female employees. Continued research on PPE issues should be conducted to reveal limitations and deficiencies. Strategies should be employed to address PPE issues.

- Mining companies should abide by the requirements of the BCEA in terms of the treatment of women during and after pregnancy. In addition, mining companies should implement the principles of the Code of Good Practice on the Protection of Employees during Pregnancy and after the Birth of a Child to protect pregnant and post-pregnant employees. Furthermore, a risk-assessment flow could be employed to ensure that pregnant and breastfeeding female employees are not exposed to significant risks in the workplace. Mining companies should also provide training and support to female employees on pregnancy-related issues, such as emphasising the need to disclose their pregnancies in order not to compromise the health and safety of the pregnant woman as well as her unborn baby.

- Mining companies should enhance their security and safety measures in order to create a safe environment for women that are working the night shift.

- Mining companies should provide training and support focusing on coping mechanisms for women working in the core business of the high-risk mining environment.

- Mining companies should only employ a woman if she is qualified to do the job, if she meets the requirements (physical and functional capabilities) of that specific job and if she is medically fit for the job.

\section{Conclusion}

The health and safety of mine workers remain a major challenge, not only for the relevant state departments but also for managers. Managers should ensure that employees are not unnecessarily endangered and that workers are fully aware of and properly trained and prepared for unusual workplace risks. Gender implications should be considered to ensure the health and safety of women employed in core mining positions and to contribute to the sustainable deployment of women in the mining sector.

\section{Acknowledgements Competing interests}

The authors declare that they have no financial or personal relationships that may have inappropriately influenced them in writing this article.

\section{Authors' contributions}

D.B. (North-West University) conducted the literature review as well as the empirical research and wrote up the article. F.C. (North-West University) acted as supervisor of the research project, assisted with the statistical analysis and reviewed the article.

\section{References}

Ashworth, G., Molapo, M., Molefe, N., Schutte, S., \& Zitha, M. (2004). Human and social issues influencing the incorporation of women into the mining workforce. Coaltech 2020. Retrieved June 17, 2011, from www.coaltech.co.za/.../Task $\% 20$ Coaltech 2020. Retrieved June 17, 2011, from
$2.8 .1 \% 20-\% 20$ Women $\% 20$ in $\% 20$ Mining.pdf

Babbie, E., \& Mouton, J. (2011). The practice of social research. Cape Town: Oxford University Press Southern Africa.

Badenhorst, C.J. (2009). Occupational health and safety considerations for the employment of female workers in hard rock mines. Paper presented at the Southern African Institute of Mining and Metallurgy, Hard Rock Safety Conference, September, Sun City, South Africa.

Benya, A.P. (2009). Women in mining: A challenge to occupational culture in mines. MA dissertation. Johannesburg: Department of Sociology, University of the Witwatersrand.

Burtenshaw, J. (2005, August). Women miners plunge to new depths. Retrieved March 14, 2009, from http://www.sagoodnews.co.za

Campbell, K. (2007, August 03). Woman miners 'No better industry', but retaining women after recruiting them seen as challenge. Mining Weekly. Retrieved May 11, 2011, from www.miningweekly.com/.../039no-better-industry039-butretaining-women-after-recruiting-them-seen-as-challenge-2007-08-03

Chamber of Mines of South Africa. (2012). Labour policy digest. Retrieved May 02, 2013 from http://www.bullion.org.za/.../Labour $\% 20$ Policy $\% 20$ Digest $\% 20-\% 202 \% 20$ August $\% 202012$.pdf

Eftimie, A., Heller, K., \& Strongman, J. (2009). Gender dimensions of the extractive industries: Mining for equity. Retrieved March 12, 2012, from http:// naturalresourcecharter.org/content/eftimie-heller-k-strongman-j-2009-'gendernaturalresourcecharter.org/content/eftimie-he
dimensions-extractive-industries-mining-equity'

Field, A. (2005). Discovering statistics using SPSS. (2nd edn.). London: Sage.

Field, A. (2009). Discovering statistics using SPSS. (3rd edn.). London: Sage.

Fourie, J.D. (2009). Managerial challenges faced in a South African platinum mine relating to women employment as required by the Mining Charter. Unpublished mini-dissertation, MBA, North-West University, Potchefstroom, South Africa.

Hancock, T. (2014). Women entering mining sector but legacy issues persist. Retrieved August 25, 2014, from http://www.miningweekly.com/article/womenentering-mining-sector-but-the-door-is-only-slightly-open-as-legacy-issuespersist-2014-08-22

Harmony Gold Mining Company. (2008). Harmony sustainable development report. Retrieved October 20, 2009, from http://www.har.co.za/files/Harmony_SD2008.pdf

Hermanus, M.A. (2007). Occupational health and safety in mining - Status, new developments and concerns. The Journal of the Southern African Institute of Mining and Metallurgy, 107, 531-538.

Israelstam, I. (2012, June 08). Labour laws protect new mothers. Polity. Retrieved May 06, 2013, from http://www.polity.org.za/article/labour-laws-protect-newmothers-2012-06-08

Lahiri-Dutt, K., \& Macintyre, M. (2006). Women miners in developing countries: Pit women and others. Burlington, VT: Ashgate.

Managing Transformation Solutions. (2011). Second Annual Women in Mining Conference, 23-25 February. Unpublished report.

Nel, P.S., Werner, A., Poisat, P., Sono, T., Du Plessis, A., \& Ngalo, O. (2011). Human resources management. (8th edn.). Cape Town: Oxford University Press Southern Africa.

Republic of South Africa (RSA). (1996a). Constitution of the Republic of South Africa, Act No. 108 of 1996. Pretoria: Government Printers.

RSA. (1996b). Mine Health and Safety Act, No. 29 of 1996. Pretoria: Government Printers.

RSA. (1997). Basic Conditions of Employment Act, No. 75 of 1997. Pretoria: Government Printers.

RSA. (1998). Employment Equity Act, No. 55 of 1998. Pretoria: Government Printers.

RSA. (2002). Mineral and Petroleum Resources Development Act, No. 28 of 2002. Pretoria: Government Printers.

RSA. (2004, August 13). Broad-based Socio-economic Empowerment Charter for the South African Mining Industry. Notice No. 1639 of 2004. Government Gazette, No. 25899, 6-17.

RSA. (2009). Mine Health and Safety Amendment Act. Government Gazette, No. 32140

RSA. (2010). Amendment of the Broad-based Socio-economic Empowerment Charter for the South African Mining and Minerals Industry. Retrieved June 27, 2013, from http://www.dmr.gov.za/publications/summary/108-mining-charterdownloads/128-amendedofbbseecharter.html

Schutte, P. (2009). Heat stress management in hot mines. Retrieved April 04, 2013, from http://researchspace.csir.co.za/dspace/handle/10204/4447 
Schutte, P.C. (2010). Fatigue risk management: Charting a path to a safer workplace. The Journal of the Southern African Institute of Mining and Metallurgy, 110, 53-55.

Schutte, P.C., Edwards, A., \& Milanzi, L.A. (2012). How hard do mineworkers work? An assessment of workplace stress associated with routine mining activities. Retrieved November 05, 2014, from http://researchspace.csirco.za/dspace/ bitstream/10204/5855/1/Schutte_2012.pdf

Schutte, S. (2011). Ergonomics as a practice for safe and healthy mining in South African mines. Newsletter on Occupational Health and Safety, 21(1), 11-12.

Singer, R. (2002, May). South African women gain ground below surface. USA Today. Retrieved August 15, 2013, from http://usatoday30.usatoday.com/news/ world/2002/05/17/women-miners.htm

South African Government News Agency (SAnews). (2013, October). Mine health safety bill out for public comment. Retrieved October 15, 2013, from http://www. sanews.gov.za/south-africa/mine-health-safety-bill-out-public-comment

Van Aardt, I., Bendeman, H., Christie, C., Gazi, S., \& Schutte, P.C. (2008). Exploratory survey of women in mining in the South African mining industry with specific regards to but not limited to occupational health and safety issues: Literature review. Retrieved November 27, 2014, from http://www.mhsc.org.za/index. php?option=com docman\&task=doc download\&gid=110\&ltemid
Vermeulen, A. (2014). Value of miners' lives must be recognised - Ramathlodi. Retrieved November 27, 2014, from http://www.miningweekly.com/article/ value-of-miners-lives-must-be-recognised-ramatlhodi-2014-11-18

Welman, C., Kruger, F., \& Mitchell, B. (2010). Research methodology. (3rd edn.). Cape Town: Oxford University Press Southern Africa.

Women in Mining Canada. (2010). Ramp-up: A study on the status of women in Canada's mining and exploration sector. Retrieved February 25, 2012, from http://0101.nccdn.net/1_5/1f2/13b/0cb/RAMP-UP-Report.pdf

Wynn, E.J. (2001). Women in the mining industry. Retrieved June 10, 2011, from http://www.ausimm.com.au/content/docs/wynn.pdf

Zikmund, W.G., Babin, B.J., Carr, J.C., \& Griffin, M. (2010). Business research methods. (8th edn.). Australia: South-Western Cengage Learning.

Zungu, L. (2011, October 20). Women in the South African mining industry: An occupational health and safety perspective. Inaugural lecture. Retrieved January 12, 2012, from http://uir.unisa.ac.za/handle/10500/5005

Zungu, L. (2012). Occupational health and safety challenges reported by women in selected South African gold and platinum mines. Occupational Health Southern Africa. Retrieved May 03, 2013, from http://www.occhealth.co.za/?/ viewArticle/1377 